\title{
近代土木遺構「東京湾第二海堡」の建設技術 一国内で初めての海上人工島の建設一
}

\author{
野口 孝俊 1 ・浦本 康二 2 ・鈴木 武3 \\ 1正会員 国土交通省 関東地方整備局 東京湾口航路事務所（干238-0005 神奈川県横須賀市新港町13番地） \\ E-mail: noguchi-t83ab@pa.ktr.mlit.go.jp \\ 2国土交通省 関東地方整備局 東京湾口航路事務所（２38-0005 神奈川県横須賀市新港町13番地） \\ E-mail: uramoto-k83ab@pa.ktr.mlit.go.jp \\ 3正会員 国土総合技術研究所沿岸海洋・防災研究部（†239-0826 神奈川県横須賀市長瀬三丁目1-1） \\ E-mail: suzuki-t92y3@ysk.nilim.go.jp
}

\begin{abstract}
第二海堡は, 軍事要塞として明治32年に人工島が䇋工し, 建設後100年が経過している，その間，第二海 堡は1923年の関東大震災によって被害を受け，長年の風浪等により劣化・損傷・崩壊が進行している．現 在, 護岸の保全を行い, その一部は当時の護岸を復旧させることを検討している. 本稿は, 工学的立場か ら, 国内で初めての海上人工島築造に対する海堡建設計画，建設技術，設計技術など明治期土木構造物の 建設技術をとりまとめ，現代技術への展開について考察を行った。
\end{abstract}

Key Words : military remains, military engineering heritage, modern historic infrastructures, fort on an artificial island in Tokyo Bay

\section{1. はじめに}

第二海堡は明治期に築造された軍事遺構であり土木遺 構でもある. 写真-1および図-1に示すように形状は「へ」 の字型で, 中央の砲台を挟んで左翼長270m, 右翼長190m, 平均幅は約65mである．横須賀観音崎より約 $6 \mathrm{~km}$, 富津 岬から $3.5 \mathrm{~km}$ の海上に位置している.

東京湾の湾口に位置寸る東京湾中央航路は, 首都圈の 経済を支える東京港，横浜港や千葉港等に船舶が入出港 する際に航行する航路であり，1日あたり約500隻を超え る船舶が航行している.

中ノ瀬航路や浦賀水道航路に近接した第二海堡の西側 は, 人工島護岸からの土砂の流出が著しく, 砲台基礎部 が波浪により侵食され，完成時には全島にあった外周護 岸（写真-2）の崩壊が進行している．その結果，島全体 の面積は, 整備面積約5万总 に対して約15\%も減少して いる状況にある (写真-3) .このような状況下において, 大規模地震が発生した際には, 護岸の崩壊や液状化現象 により, 航路内に土砂が流出することが懸念されている. そのため, 航路を保全する観点から, 土砂の流出防止対 策を講ずる必要があり, 現在, 第二海堡全体の保全措置 を実施している.

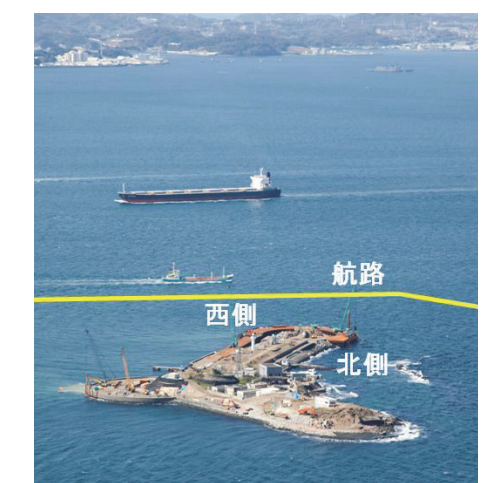

写真-1 浦賀水道航路を通行する大型船舶 (手前が第二海堡 2010年撮影)

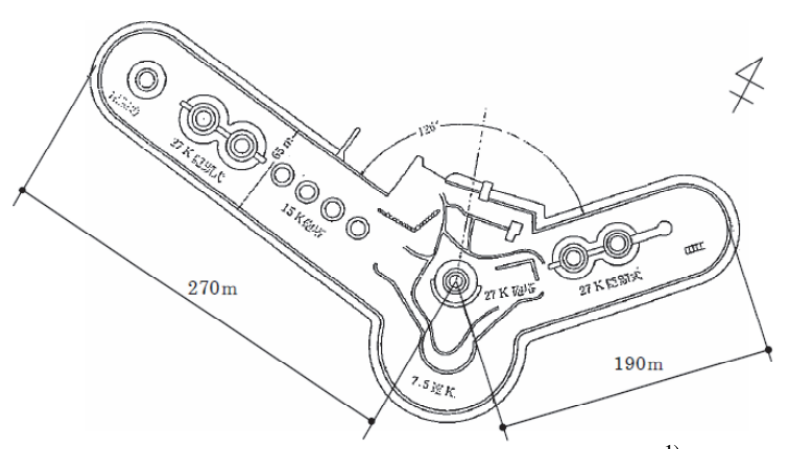

図-1 第二海堡平面図（日本築城史巻頭） ${ }^{1)}$ 
西側に比べ北側は崩壊や侵食が少なく，そこには諸外 国から東京湾への進入を防ぐために建設された砲台や煉 瓦庫が当時の状態のままの外観を残している。こうした 諸施設(海堡自体も含む)は，わが国の歴史を実体験でき る貴重な歴史的施設である．東京湾には第二海堡と同様 な施設として第一海堡と第三海堡があるが，第三海堡は 既に撤去され，建設記録だけが残されている2).

本稿は，国内で初めての海上人工島築造に関する海堡 建設計画，建設技術，設計技術などの明治期土木構造物 の建設技術をとりまとめ，現代技術への展開について考 察を行った.

\section{2. 歴史遺産としての第二海堡}

\section{(1) 遺構としての価値}

土木学会は「歴史的構造物の保全に関する研究」3)を まとめており，土木構造物の歴史的価值を示寸適切な論 点を整理している．その中で，「土木施設は公有・企業 有に関わらず人々の生活を長期間支えることが意図され た公共施設であり，ある特定の個人の判断によって処分 する訳にもいかず，一度作られれば撤去が困難な物件が 多い.つまり，工業製品や建築物と違い，世代を超えて 存続する「遺産」になりやすいという属性が元来備わっ ている.」この表現が土木遺産としての位置づけとされ る.この観点から第二海堡を考えてみると，水深の深い 海上工事としては我が国で初めてとなる「歴史的構造物」 であり「築港技術」としても土木遺産としての価值があ る.

第二海堡は, 27センチカノン砲8門, 15センチカノン砲 6門, 探照灯 1 基, 水雷用探照電灯1基が装備されている. 第二海堡の機能が軍事施設である砲台であり，鉄道や下 水道に代表される生活を支える施設ではない.軍事施設 としての位置づけも関東大震災後には廃止されている.

更に，第二次世界大戦時に米軍による爆破で砲台および 地下施設が破壊されていることから保存状態的には良好 と言えず，直ちに保存・公開するには至らない. しかし， 3.に記すように国内における本格的な海上人工島建設技 術としては，評価されるべき施設である.

\section{(2) 軍事施設としての土木構造物}

我が国の人工島の建設史を包括的にまとめた文献はな いと把握している．わが国の港湾築港創世記の歴史をま

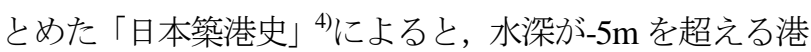
の建設については, 明治 30 年に着工した小樽港までなく, 野蒜港を初めとし水深の浅い場所に建設されている.工 事に船舶を利用しないと築造することが出来ない，いわ ゆる海上工事による人工島建設としては第二海堡が初め

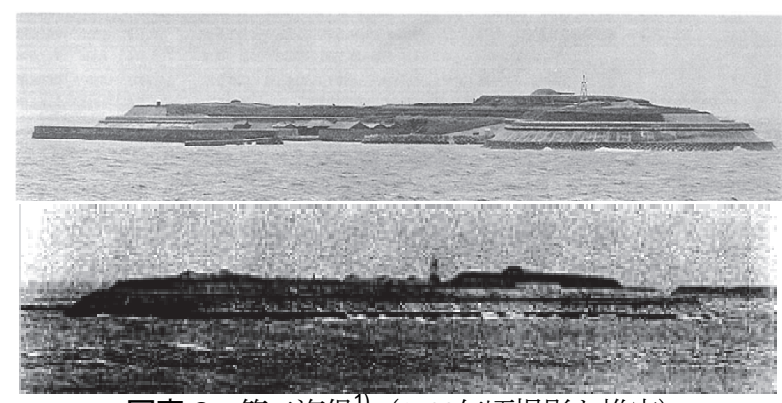

写真-2 第二海堡1)(1900年頃撮影と推定)

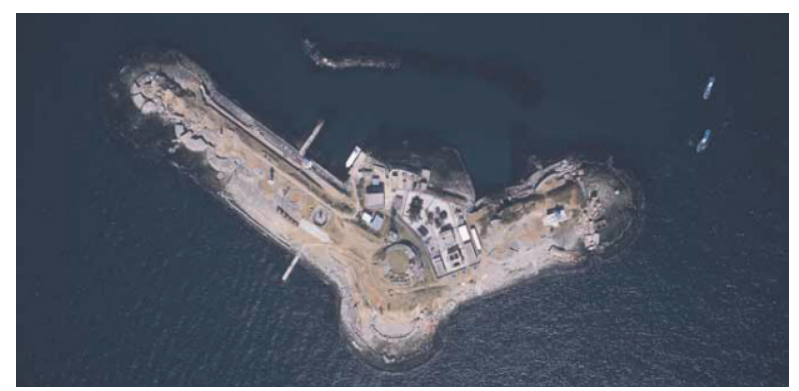

写真-3 第二海堡の浸食状況（2004年撮影）

てとなる.

浄法寺がまとめている「日本築城史」では，海中に築 島して，その上に砲台を築いたものが海堡と定義してい る。その中で，わが国における海堡の初めは，薩摩藩主 島津斉涁が，鹿児島湾防備上，最も有利と思われる位置 にある海中の岩礁や浅瀬を利用して, 祗園州・砂揚場・ 弁天波戸などの台場砲台を構築したと記載 ${ }^{5)}$ がある. 次 の海堡建設は黒船退去後の嘉永 6 （1853）年，品川沖海 中に 1 番から 7 番までの品川台場（海堡）を起工し， 1 番から 3 番, 5 番, 6 番台場が完成している. これらも水 中埋立ての深さが, $-1.9 \mathrm{~m}$ ない の埋立工事とされている.

\section{（3）地盤工学的史跡としての第二海堡}

土木学会選奨土木遺産リスト ${ }^{6}$ に登録された中では, 地盤構造物は見あたらない。ここには登録されていない が，第二海堡を初めとした東京湾海堡は，海底地盤面上 に石材による築堤を実施したうえで，築堤表面を間地石 による斜面堤とし，内部を砂で埋立てた人工島であり， 土木構造物（地盤工学的史跡）といえる.

明治期における土木技術を駆逐した地盤構造物として は，希有な構造物であり，上述の土木遺産リストにある 軍事施設分野でも, 海上における軍事施設は品川台場, 横須賀市猿島のみであり，貴重な構造物である.

\section{3. 東京湾海堡計画}

東京湾海堡の建設計画については，各記録を収集して 東京湾口航路事務所が取りまとめをおこなっている ${ }^{2)}$. 


\section{(1) 建設計画}

東京湾海堡計画は, 幕末の江川太郎左衛門による江戸 湾口海中台場計画 》に始まった。しかし，これが具体的 に動き出したのは，明治新政府が日本列島の要塞化に取 り組み，その一環として東京湾海防に取り組みを進めて からである．明治 4 年（1871），山県有朋は『軍備意見 書 ${ }^{8)}$ を提出し，日本列島の要所に海岸砲台を築くことを 提案した. 当時, 外国人軍人・技師を雇い，欧米先進技 術の導入に専心していた明治政府は，東京湾海防計画の 策定に当たっても，フランス軍人マルクリーやミュニエ 一，オランダ軍人のワンスケランベックらに計画作成を 委嘱した. しかし，この間に日本人の軍人技師も急速に 軍事・海防技術を習得し，明治14年（1881）には第一海 堡建設に着工した，そして，明治 22 年（1889），陸軍臨 時砲台建築部の黒田久孝が第二海堡・第三海堡の計画 ${ }^{9)}$ を陸軍大臣に提出し，ここから第二海堡・第三海堡建設 事業が始まっている.

\section{（2）建設経緯}

明治14年（1881），富津岬の先端の海中において，富
津海堡の建設が着工した．この富津海堡が後の第一海堡 になる. 第一海堡は9年の歳月をかけて明治23年 (1890) に竣工し，その前年の明治22年（1889）に第二海堡の建 設が着工する．第二海堡着工の3年後の明治25年 (1892) に第三海堡の建設が着工された．その後，人工島部分は 第二海堡が明治32年，第三海堡が明治40年に竣工してい る. 建設当時の状況を写真-4に示寸. 更に，人工島上部 において砲台などの軍事施設を建設し，第二海堡が要塞 として完工したのは大正3年（1914）となった.

\section{(3) 建設工事概要}

明治 39 年 (1906) に日本政府からアメリカ政府に報告 した文書「日本帝国海堡建築之方法及景況説明書」 ${ }^{10)}$ を基本資料としてとりまとめた建設概要を表-1 に示 す．三海堡それぞれの満潮面での面積は，第一海堡が $23,000 \mathrm{~m}^{2}$, 第二海堡が 1.8 倍の $41,000 \mathrm{~m}^{2}$, 第三海堡は第 一海堡と同程度の $26,000 \mathrm{~m}^{2}$ である. 第二海堡は, 第一海 堡の西方 $2,577 \mathrm{~m}$ で, 水深-8から-10m の海中に築かれた.

三つの海堡建設において，最も大きな制約となってい るのが水深である. 第一海堡地点の水深は-4.6m, 第二海

表-1 第二海堡の建設概要（第一海堡, 第三海堡）との比較

\begin{tabular}{|c|c|c|c|}
\hline 海堡 & 第一海堡 & 第二海堡 & 第三海堡 \\
\hline \multicolumn{4}{|l|}{ (人工島) } \\
\hline 着工年月 & 明治14年 (1881) 8月 & 明治22年 (1889) 7月 ${ }^{11)}$ & 明治25年 (1892) 8月 \\
\hline 竣工年月 & 明治20年 (1887) 6月 & 明治32年 (1899) 6月 & 明治40年 (1907) 10月 \\
\hline \multicolumn{4}{|l|}{ (上部構造) } \\
\hline 着工年月 & 不明 & 明治33年 (1900) 3月16日 & 大正3年 (1914) 9月以降6) \\
\hline 竣工年月 & 明治23年 (1890) 12 月 ${ }^{13)}$ & 大正3年 $(1914)$ 6月 ${ }^{13)}$ & 大正10年 (1921) 3月 ${ }^{15)}$ \\
\hline 建設期間 & 9年 & 25年 & 29年 \\
\hline \multirow{2}{*}{ 建設地 } & \multirow{2}{*}{ 富津岬の先端の海中 } & \multirow{2}{*}{ 第一海堡の西方 $2,577 \mathrm{~m}^{14)}$} & 第二海堡の南方611m ${ }^{13)}$ \\
\hline & & & 走水低砲台の北方2,589m ${ }^{15)}$ \\
\hline 海底の深さ (最深) & $-4 \mathrm{~m} 60 \mathrm{~cm}$ & $-12 m$ & $-39 m$ \\
\hline 最浅 & $-1 \mathrm{~m} 20 \mathrm{~cm}$ & $-8 \mathrm{~m}$ & \\
\hline 海底の地質 & 貝殼混合の砂 & 貝殻混合の砂 & 砂利交り砂 \\
\hline 潮流の速度（毎秒） & $1 \mathrm{~m}$ & $1 \mathrm{~m} 20 \mathrm{~cm}$ & $1 \mathrm{~m} 50 \mathrm{~cm}$ \\
\hline 満干の差 & $2 \mathrm{~m}$ & $2 \mathrm{~m} 20 \mathrm{~cm}$ & $2 \mathrm{~m} 20 \mathrm{~cm}$ \\
\hline 沈降の程度 $※ 1$ 最大 & $35 \mathrm{~cm}$ & $50 \mathrm{~cm}$ & $1 \mathrm{~m}$ \\
\hline 最小 & $20 \mathrm{~cm}$ & $30 \mathrm{~cm}$ & $50 \mathrm{~cm}$ \\
\hline \multirow{2}{*}{$\begin{array}{l}\text { 基礎上部面積 }\left(\mathrm{m}^{2}\right) ※ 2 \\
\text { 基碟上部 } 1 \mathrm{~m}^{2} \text { の価格 }\end{array}$} & 23,000 & 41,000 & 26,000 \\
\hline & 18円20弱 & 19円70弱 & 91円 \\
\hline \multirow{2}{*}{$\begin{array}{l}\text { 基礎上部 } 1 \mathrm{~m}^{2} \text { 当の荷重 } \\
\text { (明治39年当時) }\end{array}$} & 最大 $20 \mathrm{t}$ & 最大 $22 \mathrm{t}$ & 最大 $25 \mathrm{t}$ \\
\hline & & 最小18t & \\
\hline \multirow{2}{*}{ 捨石の大きさ 大型 } & 267kg以下34kg以上 & 201kg以下67kg以上 & $201 \mathrm{~kg}$ 以下 $67 \mathrm{~kg}$ 以上 \\
\hline & $134 \mathrm{~kg}$ 以下 $17 \mathrm{~kg}$ 以上 & $67 \mathrm{~kg}$ 以下 $17 \mathrm{~kg}$ 以上 & $67 \mathrm{~kg}$ 以下 $17 \mathrm{~kg}$ 以上 \\
\hline \multirow{2}{*}{$\frac{\text { 大型 }}{\text { 小形 }}$} & 円石 $2.27 \mathrm{t}$ & 方台石1.74t以上 & 方台石1.74t以上 \\
\hline & 1.74ないし $1.20 \mathrm{t}$ & $1.54 \mathrm{t}$ 以上 & $1.54 \mathrm{t}$ 以上 \\
\hline 被覆石の基脚水深 & $-2 m$ & $-4 m$ & $-3.2 \mathrm{~m}$ \\
\hline 防波堤頂上の高さ & H.W.L+6.0m & H.W.L+6.0m & H.W.L+6.0m \\
\hline 捨石材数量 $\left(\mathrm{m}^{3}\right)$ & \begin{tabular}{|l|l|}
73,264 \\
\end{tabular} & 485,968 & $2,781,864$ \\
\hline 埋填砂数量 $\left(\mathrm{m}^{3}\right)$ & 129,385 & 299,243 & 540,816 \\
\hline
\end{tabular}

$※ 1$ : 竣工時から明治39年 (1906) 10 月までの基礎の一部の沈下量

$※ 2$ : 約満潮面での面積 
表-2 築造に関わる材料数量と費用 ${ }^{2)}$

\begin{tabular}{|c|c|c|c|c|c|c|c|c|c|}
\hline & \multirow{2}{*}{ 石材 $\left(\mathrm{m}^{3}\right)$} & \multirow{2}{*}{ 砂 $\left(\mathrm{m}^{3}\right)$} & \multirow{2}{*}{ 人夫（人） } & \multicolumn{5}{|c|}{ 費用（円） } & 費用（億円） \\
\hline & & & & 石材 & 埋填砂 & 諸材料 & 職工・人夫 & 計 & 計 \\
\hline 第一海堡 & 73,264 & 129,385 & 316,776 & 172,965 & 25,230 & 69,256 & 110,872 & 378,322 & 14.2 \\
\hline 第二海堡 & 485,968 & 299,243 & 495,855 & 296,796 & 92,107 & 154,816 & 247,928 & 791,647 & 29.8 \\
\hline 第三海堡 & $2,781,864$ & 540,816 & 435,290 & $1,795,415$ & 239,365 & 197,743 & 261,174 & $2,493,697$ & 93.9 \\
\hline 合 計 & $3,341,096$ & 969,444 & $1,247,921$ & $2,265,176$ & 356,702 & 421,814 & 619,973 & $3,663,666$ & 139.2 \\
\hline
\end{tabular}

1) 工事費は埋め立て造成費のみで，大砲などの兵備費は含まない.

2）第一海堡は明治14年（1881）から明治20年（1887）までの実績值.

3）第二海堡は明治22年（1889）から明治32年（1899）までの実績值.

4）第三海堡については，明治40年（1907）3月までの予定額である.

表-3 人工島築造費用比較 (明治 - 平成)

\begin{tabular}{|c|c|c|c|c|c|c|}
\hline & 第一海堡 & 第二海堡 & 第三海堡 & 羽田D滑走路 & 関西空港II期 & 中部空港 \\
\hline 供用年 & 明治20年 & 明治32年 & 明治40年 & 平成22年 & 平成18年 & 平成17年 \\
\hline 工事期間着工〜完成 (人工島のみ) & 71ヶ月 & 120 ケ月 & 183 个月 & 41 ケ月 & 92ヶ月 & 51 ケ月 \\
\hline 埋立1日あたり施工量 $\left(\mathrm{m}^{3} /\right.$ 日 $)$ & 94 & 371 & 1,559 & 22,764 & 90,580 & 33,987 \\
\hline 埋立1日あたり施工面積 $\left(\mathrm{m}^{2} /\right.$ 日 $)$ & 11 & 19 & 12 & 2,033 & 1,975 & 3,072 \\
\hline 工事費（人工島のみ）億円 & 14 & 30 & 94 & 6,000 & 114,000 & 6,500 \\
\hline 造成面積 & 2.3ha & 4.1ha & 2.6ha & 250ha & 545ha & 470ha \\
\hline 面積当たり単偠 $\left(\right.$ 円 $\left./ \mathrm{m}^{2}\right)$ & 6,174 & 12,957 & 40,826 & 24,000 & 20,917 & 13,830 \\
\hline 埋立土（石材＋土砂） & 20 万 $\mathrm{m}^{3}$ & 79 万 $\mathrm{m}^{3}$ & 332 万 $\mathrm{m}^{3}$ & 3800 万 $\mathrm{m}^{3}$ & 25000 万 $\mathrm{m}^{3}$ & 5200 万 $\mathrm{m}^{3}$ \\
\hline 平均水深 & $-3 m$ & $-10 \mathrm{~m}$ & $-39 m$ & $-18 \mathrm{~m}$ & $-19.5 \mathrm{~m}$ & $-6 \mathrm{~m}$ \\
\hline
\end{tabular}

※羽田D滑走路は東京空港整備事務所資料(2010)，関西空港I期の数值は関西空港工事誌，中部空港の数值は中部空港工事誌より

堡は-12.0m，第三海堡は-39m である. 水深が深くなるに 伴い施工の難易度は高くなるが，さらに潮流が早い地点 であることが難工事となる．潮流の早さは，第一海堡の 場所で $1 \mathrm{~m} / \mathrm{s}$ ，第二海堡が $1.2 \mathrm{~m} / \mathrm{s}$ ，第三海堡は $1.5 \mathrm{~m} / \mathrm{s}$ と, 第三海堡の地点の潮流が一番早い.

表-2に東京湾海堡築造に関わる材料数量と建設費用 ${ }^{2)}$ を示す．捨石の量を比べると，水深の深さによってその 使用量が大きく違っている．第一海堡が73,264 $\mathrm{m}^{3}$ の捨石 に対し，第二海堡はその6.6倍の485,968m³，第三海堡は 38倍の2,781,864 $\mathrm{m}^{3}$ の石材を投入している.

第一海堡から第三海堡の建設費用については，第一海 堡建設着工年の明治14年（1881）を1.0として作成した平 成17年のデフレータ(3765)を乗じた金額を試算した。第 一海堡は約14億円，第二海堡は約30億円，第三海堡は約 95億円となる. これを現在の人工島と比較したのが表-3 である. 数值は比較するために工事誌などにより編集し たもので，それぞれ完全には同一条件ではない，対象は 最近施工の東京国際空港（羽田D滑走路），関西国際空 港II期および中部国際空港とした。いずれも人工島築造 のみで上部構造は含んでいない，また，費用については 供用当時金額である.

規模および設置水深などの違いはあるが，造成単位面 積当たり単価の比較をしたところ, 水深の浅い第一海堡 が一番安く，第二海堡が 1.3 万円 $/ \mathrm{m}^{2}$ となり平成に築造さ れた大規模人工島と同程度の単価となっている. 第三海 堡は最も面積当たりの単価が高くなっているが，水深が 深い箇所に対応した施工機械がないこと，施工期間が長
いこと，施工条件が厳しいことが原因と想定される.

一日当たりの造成面積を試算した，明治期では20 $\mathrm{m}^{2} /$ 日以下であるが，現代の人工島築造は2,000 $\mathrm{m}^{2} /$ 日程度と 100倍以上も施工能力が向上し, 着工から竣工までの施工 期間が圧倒的に短縮されていることがわかる.

造成される面積当たりの施工単価が現代と大きく変 わらないのは，現代は大型機械を投入することで施工能 力が大きくなり，施工期間を大幅に短縮することが可能 とはなったが，その機械の設備費も比例して高くなるこ とから施工単価的には変わらないものと推察される.

\section{4. 東京湾第二海堡建設技術}

第二海堡の建設技術については，前述の「日本帝国海 堡建築之方法及景況説明書」における原文の旧仮名遣い から現代仮名遣いにした内容をそのまま a)以下に示し た. また，他の文献から施工状況を補足するとともに，

「港湾の施設の技術上の基準・同解説」に記載された技 術と比較することで第二海堡の建設技術が，現在の技術 の系譜となっているか考察しb)に記載した.「日本帝國 海堡建築之方法及景況説明書」の構成は，緒言（建設条 件），第一海堡，第二海堡，第三海堡の順番で施工につ いて記述されている. 第二海堡の内容は a. 基礎工建設, b.護岸築造, c.盛土, d. 支持力, e.洗掘, の記述がある. この説明書において，米国から日本の建設技術力が高く 評価されている ${ }^{17)}$. 


\section{（1）建設条件の決定}

a) 第二海堡が位置する海底の地質は, 第一海堡と同じく, 貝款を混合した砂層である. 水深は-8.0m〜-10.0m，潮流 は $1.2 \mathrm{~m} / \mathrm{s}$ である．第二海堡付近では波高が $2 \mathrm{~m}$ に達する ことがあるが，その破壊力は猛烈ではない，風は一年を 通じて北風が最も多く, 夏期には南風が多い. 最大風力 は 35m/sec に達することがある，そして，東南方向を除 くと，吹送距離が短いので大きな影響を蒙ることはない が，外海から侵入する波浪は，風の方向の如何に関わら ず，工事上，最も警戒を要するものであり，もし，この 波浪が風速の大きな南東風を伴うと，その破壊力は実に 猛烈を極める.

b) 潮位は図-2 から判るように H.W.L で+2.2m, H.W.L で+0.0m との記述があるが，現在の東京湾に建設される 際の設計潮位とほぼ変わらないことから，地盤高さの測 量技術および潮位観測技術は現在と変わらない精度を有 していることがわかる．風速・波浪については具体的な 数字は少ないが，防波護岸として必要な設計・施工条件 の観測を実施しており，現在基準の考え方における先駆 であることが判る.

\section{（2）防波堤基礎工}

a) 外側を堅石で被覆し, 波の衝撃に抵抗させた. 堅石と は安山岩であって，その性質は硬く密であり，長く風雨 にさらしても酸化したり, 崩壊することもなく, 比重 2.4 を下ることはない，そして，被覆に使用した堅石の形状 は長斜方形で，1個の大きさは約 26 立方尺 $\left(0.083 \mathrm{~m}^{3}\right)$ ないし $1 / 4$ 立方尺 $\left(0.007 \mathrm{~m}^{3}\right)$ の軟らかい割栗石を防波堤 基礎の形状にあわせて捨て込み，満潮面下約- $1 \mathrm{~m}$ の深さ まで，数力月間，波浪の影響を受けさせ，各捨石が充分 に沈下して安定するのを待った. b) 図-2は建設当時の図面から使用材料の標記を明記し たものである．護岸形状は，現在の「港湾の技術上の基 準」 ${ }^{19)}$ の考え方と照らしても同様な考え方で構築されて いる. 基礎マウンドの勾配については海底面(-10.0m)から -8.2mまでは，1：2の勾配で築造した後，-3.2mまで1:5の 自然勾配で築造している．第二海堡の基礎マウンドを合 成勾配として計算すると2.73となるが，港湾基準では基 礎マウンドの法勾配を1:3の標準としており，ほぼ現行と 同程度となる．-8m以下は波力が小さくなることを考慮 すれば勾配は小さくて済むため，このことを考慮すれば 第二海堡は合理的な基礎マウンドである.

基礎に使用した堅石については，第二海堡と第三海堡 海堡の資材調達を請け負った「永島家文書」 ${ }^{18}$ に基礎石 の材質に関する記録から検証することができる．基礎の 積み上げに使用した石材は軟らかい割栗石で，砂岩およ び㠜死岩の一種からなり，多少の粘土を含んでいるとの 記述がある。

大正3年 (1914) に横須賀市走水から採取された粟石に 関しては特に「軟石」と記載されていて，横須賀市勝力 (現地名は泊町) 採取の粟石とは異なる石質であるとし ている．横浜地方から三浦半島に広く存在する岩質第三 紀層水成岩で良質のものを粟石と称し，鷹取石（横須賀 市鷹取）と称している．更に普通の品質のものを三浦割 栗石と称したとある．ただし，防波堤に使用した石材は 海堡より, 海上約 $80 \mathrm{~km} の$ 距離にある真鶴の採石場で産出 したものを使用したが，この石材は純粋な火山岩で，安 山岩の一種である.採取された石種標記は粟石で統一さ れているが，複数の土源を有していることが判る.

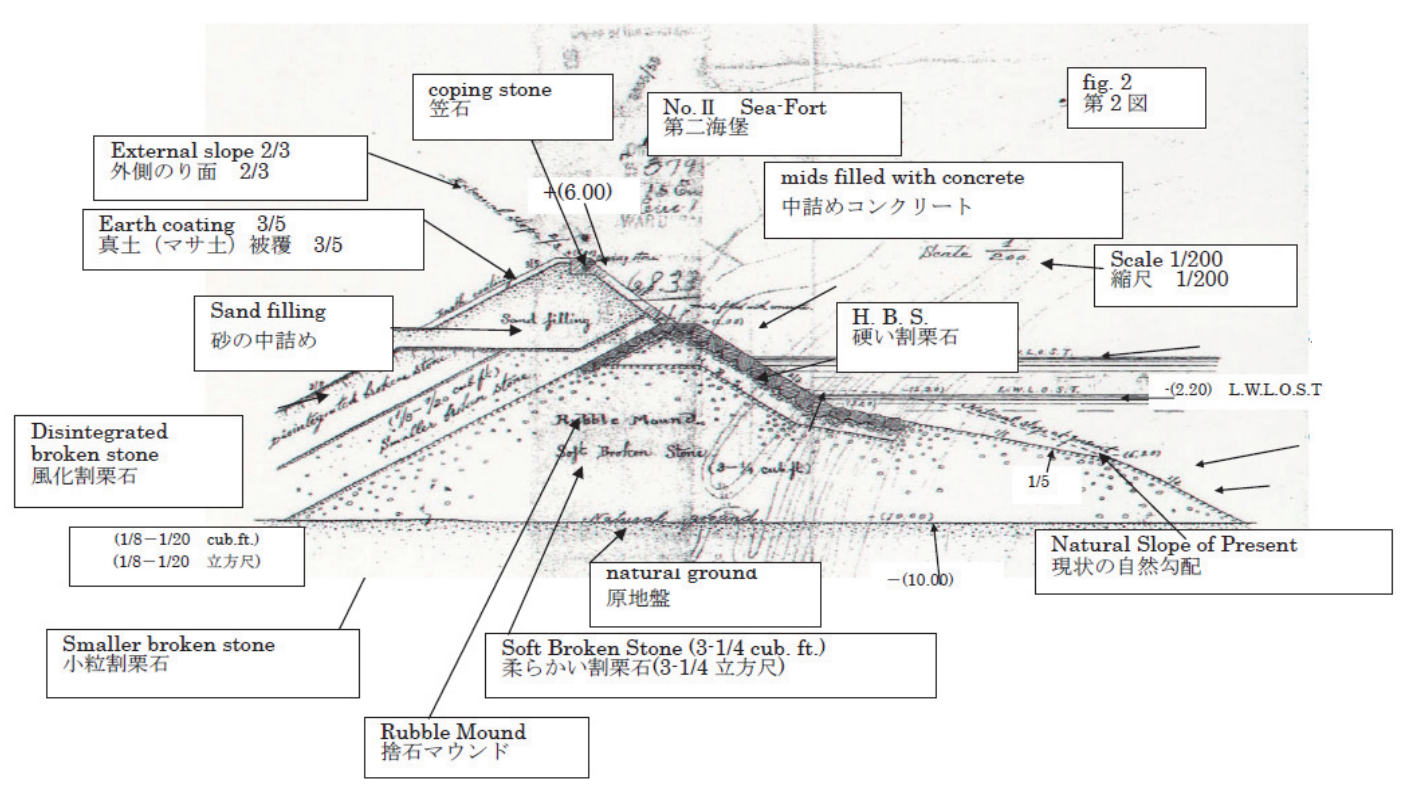

図-2 建設当時の第二海堡防波護岸図 米国公文書館（NARA）蔵 (1926.9.5)のコメントを明記 


\section{(3) 護岸築造技術}

a) 第一海堡の実験に基づき，先ず 3 立方尺 $\left(0.083 \mathrm{~m}^{3}\right)$ ないし $1 / 4$ 立方尺 $\left(0.007 \mathrm{~m}^{3}\right)$ の軟らかい割栗石を防波堤 基礎の形状にのっとって捨て込み，満潮面下，約 $1 \mathrm{~m} の$ 深さに達しさせ, 数力月間, 波浪の影響を受けさせ, 各 捨石が充分に沈下して安定するのを待ち，第二図のよう に，外側を堅石で被覆し波の衝撃に抵抗させた．堅石と は安山岩であって，その性質は硬く密であり，長く風雨 にさらしても酸化したり崩壊することはなく, 比重 2.4 を下ることはない，そして，被覆に使用した堅石の形状 は長斜方形で, 1 個の大きさは約 26 立方尺 $\left(0.723 \mathrm{~m}^{3}\right)$ ないし 23 立方尺 $\left(0.640 \mathrm{~m}^{3}\right)$ で，その面は約 $1 \mathrm{~m}$ の正方 形とし. 長さ，すなわち，控えは約 $1 \mathrm{~m}$ とした.

堅石を積み重祆るには，器械潜水夫によって防波堤基 礎の上部を所要の深さ, 寸なわち, 約 $4 \mathrm{~m}$ に掘削し, 硬 い割栗石を厚さ約 $50 \mathrm{~cm}$ に敷き均し，その上に勾配 $2 / 3$ に堅石を積夕重ね，満潮面上 $2 \mathrm{~m}$ に達しさせた．水平女 るいは任意にするのではなく, 45 度の勾配に積み重ねた。 この目的は, 捨石沈下のため積み重ねた石が変位するの で，その影響をなるべく軽減することであったが，その 結果は極めて良好であった，捨石基礎の内側には，砂留 めのため，軟石の小片や破片をそれぞれ厚さ $3 \mathrm{~m}$ の 2 層 に投入し，捨石面に存在する空隙を完全に塞いで砂の脱 出を防ぐ処置をとったのち，内部に砂を充填した.

第二海堡において，波浪が捨石に影響を及ぼす深さは 満潮面下, 約-5m 前後で, 波の勢力が最も強いのは干満 平均水面付近である。したがって，これらの張石（間地 石）は満潮面下-3.2m から+4.5m の深さに位置している. b) 近代港湾築造の年次と整備概要を後述表-4 に示寸. -10m を超える水深であること, 防波の機能を有した護岸 築造は第二海堡が初めての施工と考えられる. 当然とし て設計施工基準はなく，新たな技術の採用に対して，試 験を実施して，経過を確認した上で施工していることが 確認できる．現在においても新工法や㲘案課題がある工 法の実施に際しては試験施工を実施した上で，本施工を 実施しており，海洋構造物築造技術の基礎となったと言 える.

水深が- $2 \mathrm{~m}$ 程度の第一海堡のように最初から石垣を築 くことはできず，まず海底に割栗石を投入して海面上ま で積み上げ，その上に石を積み上げて堤体を形成させて いる（写真-4）。海面+4.3m までは間地石で波浪に対応 し，その上部はコンクリートで被覆している．堤内地背 後は砂で中詰めしているため, 越波による埋立地を保護 するための技術である．抜けだし防止を図るため張石を する必要があるが，「軍事機密大日記」 ${ }^{20}$ には「官有石 材採取場の石材が枯渇しつつあり，防波壁上部にはコン クリートを使用することで, 波浪ならびに敵弾に対して, より強固になるとともに施工速度も上がる」との記載が

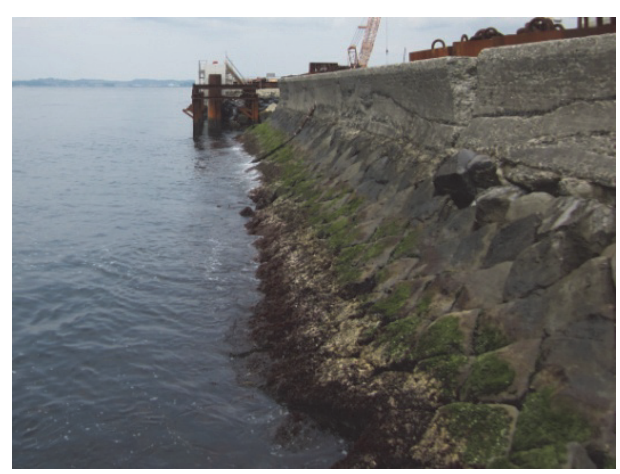

写真-4 護岸断面（間知石）

あることから，当時は使用実績のないコンクリートを使 用したものと思われる.

埋立砂の調達に関しては, 「永島家文書」 ${ }^{18)} に$ 記載が残 されている. 永島庄兵衛が千葉県君津郡富津村富津の森 田伝吉ら $21 人 の$ 船主と取り交わした，第二海堡建設用の 砂の採取と運搬・陸揚げのための船舶借り上げの契約書 である.これにより，東京湾海堡の建設に当たって富津 の船舶を大いに活用したことが分かる.

\section{(4) 埋立盛土技術}

a) 海堡敷地内に埋めた砂は, 満潮面以上は厚さ $20 \mathrm{~cm} の$ 層ごとに散水締め固めを行った。この締め固めを行うか 否かにより，基礎の支持力に大差が生じた，実験によれ ば，その差は $1: 3$ の比であった. 上部に構築する砲台堤 体工事の基礎は，これらの締め固めを行った砂層上に設 けた，そして，構造物基礎の下面は，満潮面上，若干の 高さに置く必要がある. 埋めた砂の支持力は，水中にお いては非常に不十分になるので, 構造物の重量を負担し, また，これを広い面積に等しく分担させるには，水面以 上に存在する砂層間の凝集力と砂粒間の摩擦とによらざ るを得ないからである，第二海堡の例によると，この厚 さを $2.50 \mathrm{~m}$ と寸れば，多少の沈下を見込んでも安全であ る. いかなる場合でも，これを $1.50 \mathrm{~m}$ 以下に減ずること は好ましくないとしている.

b) 盛土に関しては, 現在も盛土施工で実施されている水 締固めを実施している．砲台基礎に対して地震時でも一 部変状を起こしているが崩壊がないのはこの施工が有効 であったことが推定される.

防波堤築造における沈込量の計算は，現在でも正確に 推定するのは難しい. 柔らかい割栗石が約 $8 \mathrm{~m}$ 厚さあり, $5 \%$ が圧縮するとすれば $0.4 \mathrm{~m}$ となる。海底地盤への初期 沈下を $0.5 \mathrm{~m}$ と考えれば, 合わせて $1 \mathrm{~m}$ 程度となり基礎地 盤の沈下および基礎マウンドの圧縮量を含んだ必要厚さ の考え方は妥当と考えられる. この考え方と計測数值に ついては，参考值としてその後の港湾築造技術に反映さ れたものと推測される. 


\section{(5) 支持力試験の実施}

a) 第二海堡における砂層の負担力は, 3 カ年にわたる綿 密な試験によって決定された，その方法は，試験する心゙ き砂層を平坦にし，大きさ $1.5 \mathrm{~m}$ 立方のコンクリート塊 をこの位置に据え，その上部に鉛材 100 トンないし 50 トンを積み，数ヶ月あるいは数十ヶ月間，毎日，その沈 下を検査し, 縦座標に沈下曲線を描き, 弾性限界（最初 は加重と沈下が正比例をするが，ある重量以上は沈下量 が極めて大きくなる．この極限を仮に地盤支持力の弾性 限界と名付ける. ) 老求め, 次に許容支持力を決定した. この方法によって検定した弾性限界は $37 \mathrm{t} / \mathrm{m}^{2}$ である. も し, 水中の砂層の状況が不良の時はその半数, 寸なわち, 約 $18 \mathrm{t} / \mathrm{m}^{2}$ を許容支持力として採用し，その状況が良好な 時は $30 \mathrm{t} / \mathrm{m}^{2}$ を安全に負担させることができるであろう. 実際，第二海堡において海底より砂を積み上げた部分は $20 t / m^{2}$ の重量を加えて 1 年を経過しても沈下量はわずか に23mmに過ぎなかったと記載される.

b) 現在でも, 護岸建設における沈下量を的確に計算する ことが，工期・工費という観点でプロジェクト成功の有 無を左右するが，実際の現象を試験的に確認して施工す ることの重要性を後世に示したことになる.

\section{5. 関東大震災による被災と耐震技術への展開}

本章では，東京湾第三海堡建設史に取り纏められた資 料を基に, 関東大震災による被災事例から, 被害実態を 推測し, 今後の大規模地震の影響について推定するもの である.

\section{(1) 関東大震災による被害記録}

大正 12 年（1899） 11 月に作成された「東京湾要塞防 禦営造物ノ震害二関スル調査並研究」 ${ }^{21)}$ では, 関東大震 災による東京湾海堡の震害が次のように記されている.

1) 各海堡の基礎の破壊状況は, 水深に比例している. 第 一海堡の基礎の破壊は極めて少ない．第三海堡の防波壁 は全部, 転倒している. 第二海堡の基礎の破壊状況は, その中間である. 荷重と歳月の経過により漸次基礎粟石 間の空隙は減少していたが今回の激震では各粟石が互い に移動して，さらにその空隙を減少させ，一方栗石稜角 が磨耗し基礎の外面の粟石は一部転落し急速に全容量を 縮小した．放捨栗石の量も大きく体積が大きいものは基 礎の強度は薄弱であったことが原因で起きた。

2) 各海堡の防波壁内部に充填してある砂の一部は消失 し, 諸所に空隙が発生している. これは, 基礎捨石の空 隙内に入り込んだものと基礎護岸・石垣・防波壁の破孔・ 亀裂から侵入する海水のために流出したものであろう.

3）上部構造物の被害度は, おお括社基礎破壊の程度に比
例している．第一海堡では，被害は極めて少ない，第二 海堡では，壁体構造物のドームや壁に縦横に大亀裂が生 じ，壁の一部が破壞され，掩蔽（えんぺい）部は前方に 傾いてしまった．第二海堡では震動は第三海堡より少な いと考えられるが, ドームや脚壁に大きな亀裂を生じた. 第三海堡では壁体構造物はすべてコンクリートを用いた が，第二海堡では経費節減のため脚壁・奥壁を煉瓦造り とし，その他をコンクリート造りとした．第二海堡のド 一ムや脚壁の大きな被害は, 脚壁下の基礎コンクリート が相互連絡していないことと煉瓦造りの耐震性が低いこ とが原因であろう、第二海堡の結果から，ドームの耐震 性は高さ・直径比が大きく, 直径が小さいほど大きいこ とが判った.

4) 第二海堡の中庭の (東西 $60 \mathrm{~m} \times$ 南北 $17 \mathrm{~m}$ 余) は, 約 $1.7 \mathrm{~m}$ 隆起し，その一隅の鉄筋混凝土造りの貯水池（長さ $6 \mathrm{~m} \times$ 幅 3m×深さ1.8m）4個はそれぞれ若干傾斜して隆起した が，鉄筋貯水池は全く亀裂が発生しなかった．鉄筋貯水 池の耐震性の高さを証明している.

5) 第二海堡では，多くの砲塔は傾斜したが， $15 \mathrm{~cm}$ 砲塔 のみ原形を維持している。これは保塔の下に杭打基礎を 施してあったからである．関東大震災後の「軍事機密大 日記」 22)では，第三海堡は除籍扱いとなっているが，第 一・第二海堡は除籍には值せずとの記載がある。護岸等 の沈下被害はあるものの, 人工島までは決定的な損害を 受けていないことが想定される.

上記の記録からは，まさしく現在の而震設計につなが る貴重な報告がされている. 土木は経験工学と言われて いるが，このような過去の記録も含めて，現在の設計・ 施工の工事記録や被災報告も併せてデータベース化する ことが今後の技術向上につながるものであると言える.

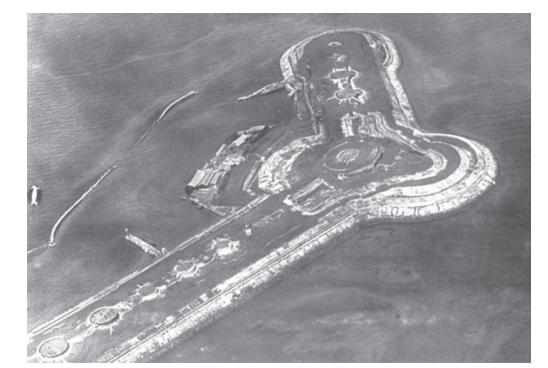

写真-5 関東大震災後の第二海堡（1923.9.9 撮影）

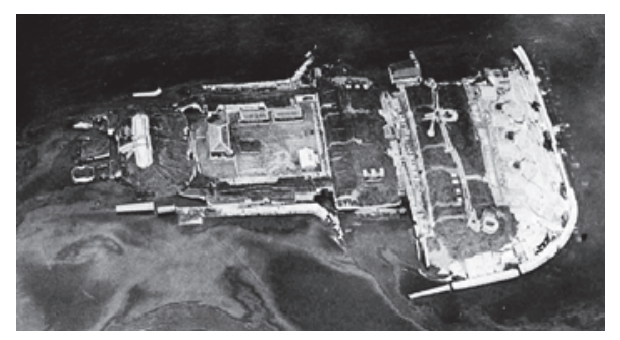

写真-6＼cjkstart関東大震災後の第三海堡（1923.9.9 撮影） 
図面縮尺

$\mathrm{H}=1: 2,000 \quad \mathrm{~V}=1: 1,000$

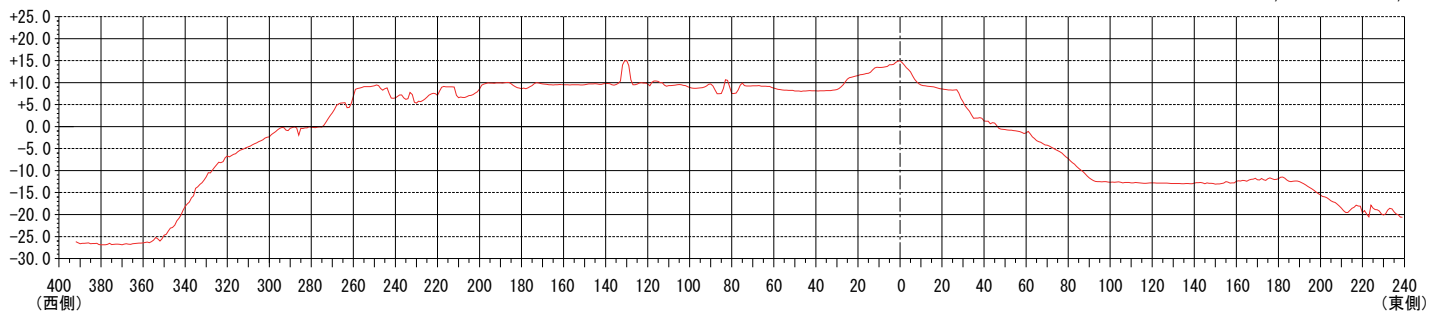

図-3 第二海堡縦断図

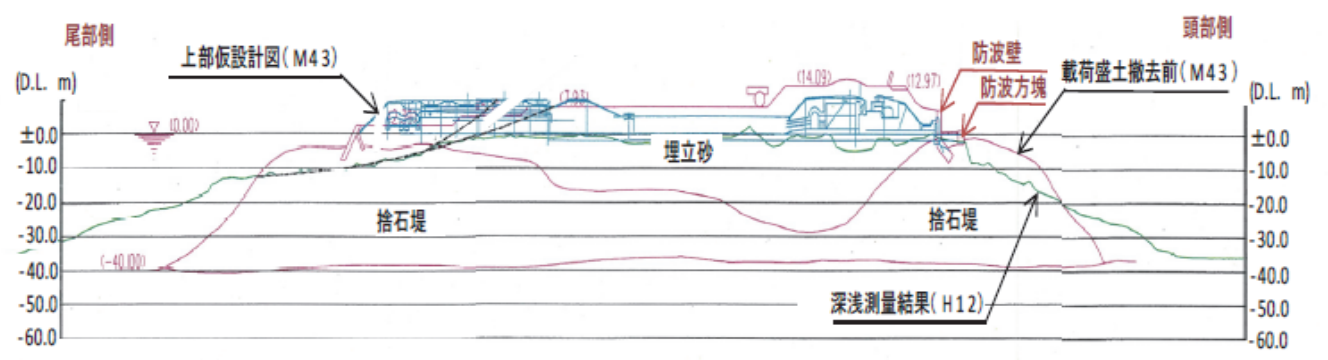

$\begin{array}{lllllllllllllllllllllllllllllllllll}0 & 200 & 220 & 240 & 260 & 280 & 300 & 320 & 340 & 360 & 380 & 400 & 420 & 440 & 460 & 480 & 500 & 520 & 540 & 560 & 580 & 600 & 620 & 640 & 660 & 680 & 700 & 720 & 740 & 760 & 780\end{array}$ 図-4 第三海堡縦断図

\section{（2）過去の地震被害推定}

写真-5 には関東大震災後の第二海堡の航空写真 ${ }^{23)}$ で ある. 写真からは被害実態の詳細を把握することができ ないが，写真上部左側（北側）が沈下により崩壊してい る様子が伺える. 更に, 写真-6 には第三海堡の被災状況 を示す，上記報告では，第三海堡の基礎の破壊が著しい のは，「第一には，捨石量が多く，それらが移動，空隙 縮小，海中への転落を起こしたからである．第二には， 高さ幅比が大きかったからである.」としている.

第二海堡の記録は無いが, 2004 年に撮影した写真-2 と 比較すると，護岸が海側に側方流動をおこし，埋立地内 は液状化現象に伴う地盤沈下が生じたものと推測される.

図-3に現在の第二海堡の形状の測量結果をしめす. 図 で左側が航路側で水深は-25m から急激に浅くなり, 平均 で-10m 程度の平地となっている. その平地に人工島を築 造している．護岸高さは+6m であり，一番標高の高い 施設は+15m である. 全体高さ (H) では約 20m, 幅 (B) は約 $100 \mathrm{~m}$ であり，H/B は 0.2 となる. 地震時には全体盛 土厚さ $20 \mathrm{~m}$ に対して 7\%圧縮したと推定すると $1.4 \mathrm{~m}$ 程度 となり，概ね文献記録から読み取れる值と同程度と推測 される．また，護岸勾配は第三海堡のような急角度では ない.

第二海堡の変位推定だけでは被害程度が解りにくいこ とから，第三海堡の被災（写真-6）と比較する．第三海 堡の深浅測量図に建設当時の上部構造図（青線）と地盤 高さ（緑線）を重㸚わせた縦断図を示したのが図-4で ある ${ }^{24)}$ ，海底水深が-39m から高さ+2.3m までの+41.3m におよぶ捨石堤を築造している. そこから+8m の防波壁
築造し $+8 \mathrm{~m}$ の平場を造成している. 全体の盛土高さ $(\mathrm{H})$ は-39m+8m=47m, 幅 (B) は約 $92 \mathrm{~m}$ であり, その比率 $(\mathrm{H} / \mathrm{B})$ が 0.51 となる. 図面上で建設当時の地盤高さと現在の高 さを比較すると $3 \mathrm{~m}$ 程度沈下しているが, 在来地盤は地 盤強度が $\mathrm{N}$ 值 20 以上の洪積層であることから圧密沈下 は想定できない，従って，関東大震災による沈下量は約 3m と推定される. 全体盛土量の約 7\%が沈下したと試算 される. 現在, 人工島捨石堤の地震による圧縮量（沈下 量）はどの程度かを推定する場合には，この数字が現在 の基礎マウンド造成における圧縮量の目安（実績）とな る.

\section{(3) 耐震設計への展開}

第二海堡の建設は明治 23 年から明治 32 年に実施され ている．この間には，明治 24 年濃尾地震（1892），明治 27 年（1894）の東京地震，明治 29 年（1896）三陸大津 波が発生し, 国内での震災予防調查会が明治 25 年に発足 し，各地震を調査しているとの記録がある．傾斜堤は大 きな崩壊は無かったが，島内の構造物に大きな影響が発 生したのは，埋立に使用した砂の液状化現象による不同 沈下が生じた結果であると推定される．第二海堡は地盤 の支持力試験や護岸の安定に関して沈下試験を実施して いるなど先駆的な実験をしているにも関わらず，地震後 の調査記録では砂の液状化現象や震度などに関する記載 が無いことから, 国内では, 地震を研究する体制はあっ たが，護岸構造物に対する而震設計の検討は始まってい なかったと推測される. 
表-4 明治年間着工主要港湾と東京湾海堡（人工島のみ）の築造概要

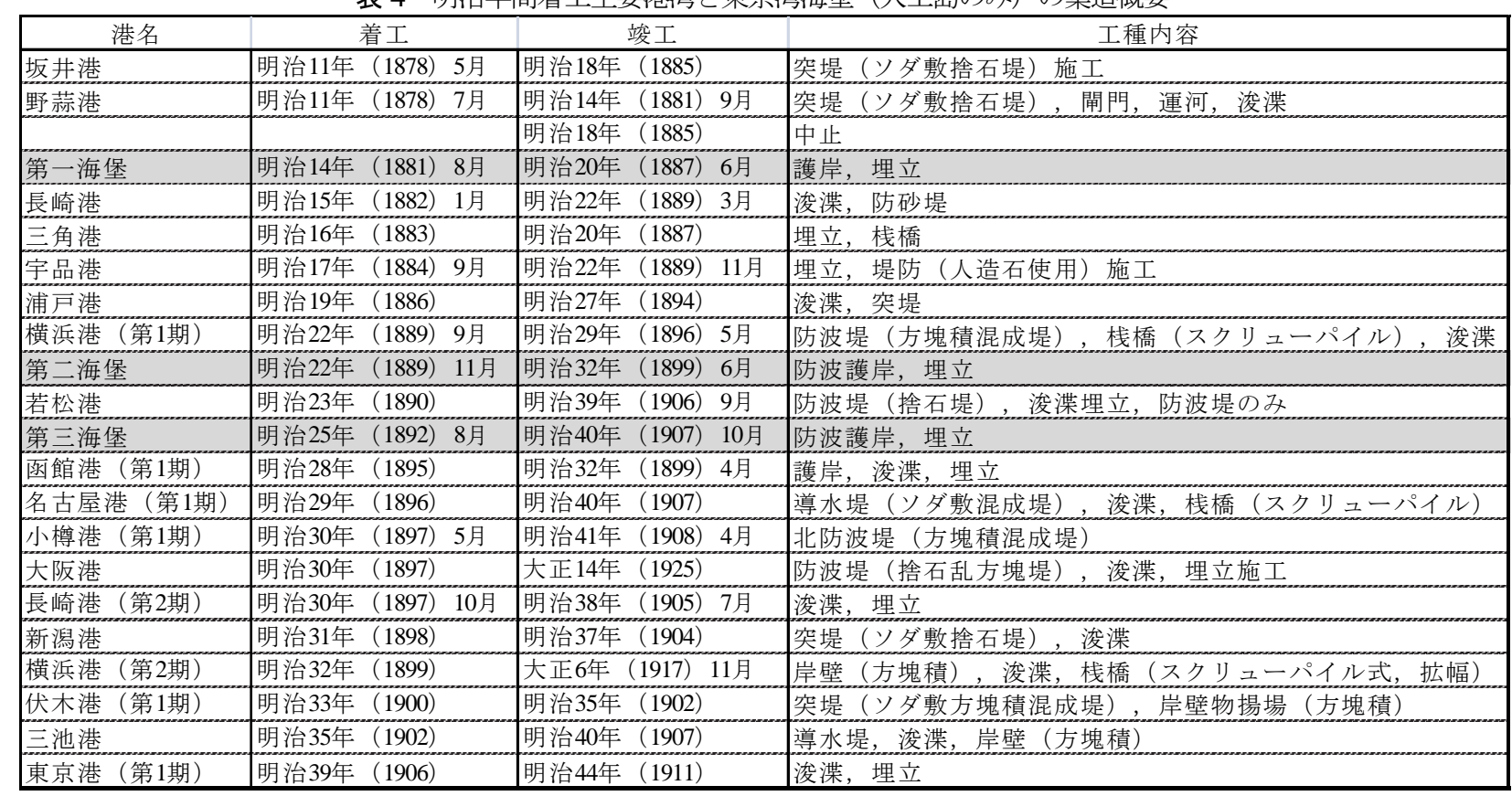

\section{6. 港湾築造への影響}

\section{(1) 港湾築造技術への影響}

4 章に記載した基礎マウンド，護岸築造，埋立地の支 持力試験と当時の建設技術と現在の設計事例を比較した が，現在の港湾基準で示された考え方と，第二海堡の断 面は，ほぼ同等の值で設計されていることから，当時の 技術力の高さとその後の港湾築造技術へ与えた影響が推 測できる.

表-4 に明治年間に竣工した主要港湾と東京湾海堡の 築造年次について「土木技術の発展と社会資本に関する 研究」 25)を基にして取りまとめを行った．第一海堡の築 造前に港湾の築造を着手したのは福井県三国（坂井）港 (明治 11 年) と宮城県野蒜港(明治 11 年)の二港だけである この二港は河口と運河を利用した港湾であり，東京湾海 堡のような本格的な海上施工ではない. その後，長崎港

(明治 15 年), 横浜港（明治 22 年）と続き, 第二海堡, 第三海堡と着工が続く。「日本築港史」 26)では廣井が工 事監督した小樽港 (明治 30 年) の築造技術が記載されて おり, 海底の載荷力, 捨石の移動, 波浪の動作, 混擬土 （コンクリート）塊の而海水質などを調査したとある.

第二海堡は陸軍築城部, 小樽港は内務省の施工であり, 各機関の教範は異なると思われるが，同時期に建設され た技術として参考にしたものと推測される.

\section{(2) 国内で初めての海上人工島}

江戸時代に海外交易の空口となった長崎出島が我が国 で始めての人工島であり，人工島は現在までに多く築造 されている。しかし，その多くは，高度経済成長期にお
ける臨海工業地帯の埋立地が多く，比較的陸地に近い場 所から整備されたものである. 第二海堡のような沖合に おける人工島は施工例が少ない，現代において，第二海 堡と同様に水深-10m 以上の沖合に建設されている人工 島は，関西国際空港，中部国際空港，東京国際空港（D 滑走路）を初めとする海上空港が第二海堡と同様な護岸 構造を採用している. 更に，大水深に建設された第三海 堡-39m）築造が先駆的事例となっている東京湾の人工島 としては，東京湾アクアライン木更津人工島（うみほた る約-20m）がある. 現代まで数えても第三海堡の建設 技術は，大水深人工島として技術的系譜に刻まれる技術 力であるといえる.

\section{(3) 新技術の導入}

現在の人工島築造技術では，海底地盤の沈下や捨石マ ウンドの安定性，埋め立て地内での支持力確保などが設 計上重要な検討項目である.第二海堡建設前の港湾では, 水深の浅い場所に築造されたため, 必要が無かった技術 である. 第二海堡は-10m 以上の水深があり, 従来の伝統 的な石積み技術だけでは築造することが出来ないので, 試験工事や波浪などの自然条件調査を実施した上で，築 造するに至っている. 更に, 漁業で利用が始まった器械 潜水を採用して水深の深い場所での施工を可能にさせた ことは，新技術の採用を行うことの重要性を再認識させ る. 第二海堡・第三海堡の建設には千葉県富津地区から の人夫を多く採用していたこと, 富津地区で行われてい た潜水器採貝漁を取り入れたことが ${ }^{27}$ 初めての人工島築 造を可能にさせたものである. 


\section{7. おわりに}

本稿では，東京湾口にある近代土木遺構である第二海 堡の建設概要を取りまとめ，人工島築造から 100 年を経 過した明治期土木構造物の建設技術を確認し，建設記録 をとりまとめた上で，港湾構造物築造技術への影響と現 代技術への展開について考察を行った.

建設記録では，波浪時における基礎捨石の安定や支持 力試験の実施など, 現代土木工学の礎とも思える埋立工 法の設計・施工が実施され，幾度の台風による被災や関 東大震災での被害を受けても, 現在まで土木構造物とし て存在している。 その技術は，各地の軍港や小樽港を初 めとした近代港湾築造技術に引き継がれ，国内振興の拠 点を形成することに繋がっていることが推定される.

\section{参考文献}

1) 浄法寺朝美：日本築城史，原書房，中表紙，1971.12.

2) 国土交通省関東地方整備局東京湾口航路事務所 : 東 京湾第三海堡建設史，2005.3.

3) 土木学会歴史的構造物保全技術連合小委員会 : 歴史 的構造物の保全に関する研究，2008.5.

4) 廣井勇 : 日本築港史, 丸善, 1927.5 .

5）浄法寺朝美：日本築城史，原書房，p.112, 1971.12.

6) 土木学会土木史研究委員会 : 日本の近代土木遺産, 2005.12 .

7) 大日本維新史料：編年之部, 嘉永 6 年 7 月 25 日 (1853.8.29），東京大学史料編纂所蔵

8) 山県有朋, 河村純義, 西郷従道 : 山県兵部大輔外二 名ノ内地ノ守備, 沿海の防御及ビ軍須二関スル献議, 陸軍築城部本部（編）「現代本邦築城史第 1 部第 1 巻築城沿革附録」，1943.4，国立国会図書館蔵， 1871.12.24.

9)陸軍築城部本部（編）：黒田久孝「増設海堡候補地 ノ海面調査復命書」，1889.6.24，「現代本邦築城史 第 2 部第 1 巻東京湾要塞築城史附録」, 国立国会図 書館蔵, 1943.4.
10) 日本帝国海堡建築之方法及景況説明書, 米国公文書 館（NARA）蔵，1906.10.3.

11) 東京湾防御第二海堡基礎試築成績書 : 陸軍築城部本 部（編），1891.6.17.

12) 陸軍省：「軍事機密大日記」明治三十四年東京湾要 塞検閲報告, 防衛研究所蔵, 1901.4.25.

13) 陸軍省: 東京湾要塞海堡ノ略説, 防衛研究所蔵, 1906.

14）浄法寺朝美：日本築城史，原書房，pp.113，1971.12.

15）（社）工学会明治工業史発行所 : 明治工業史土木篇, pp.866, 1929.7.31.

16) 村田淳 : 第三海堡基礎上部建築致度件伺，1914.3.26； 陸軍省「軍事機密大日記」, 防衛研究所蔵から推定

17）森永真朗, 島崎武雄 : 明治時代の日本から米国への 東京湾第三海堡建設技術移転に関する研究, 土木史 研究講演集, Vol.24, pp.293-304, 2004.

18) 永島家文書：富津の船主と永島家との砂運搬船に関 する「契約書」，横須賀市自然・人文博物館蔵，1897.

19）日本港湾協会 : 港湾の施設の技術上の基準・同解説, 2007.

20) 軍事機密大日記 : 東京湾要塞第三海堡防波壁構築仕 様変更乃件, 1901.6.26.

21) 陸軍築城部本部（編）: 東京湾要塞防御栄造物ノ震 害二関スル調査並研究，現代本邦築城史第 2 部第 1 巻東京湾要塞築城史附録，1923.11，国立国会図書館 蔵, 1943.4.

22）陸軍省：軍事機密大日記, 東京湾要塞堡塁砲台ノ一 部廃止二関スル件照会, 防衛研究所蔵, 1925.5.1.

23）日本海軍「震災飛行偵察報告ノ件」, 防衛研究所蔵, 1923.

24) 国土交通省関東地方整備局東京湾口航路事務所 : 平 成 13 年度東京湾口航路第三海堡而震検討調査報告書, p.85, 2002.3.

25) (社) 土木学会(編)：土木技術の発展と社会資本に関 する研究, 総合研究開発機構, 1985.7.

26) 廣井勇：日本築港史，丸善，pp.145-148，1927.5,

27) 花木宏直, 山漫菜穂子 : 東京湾要塞地帯における第 二・第三海堡の建設と住民の対応, 歴史地理学野外 研究, 第 14 号, pp.1-30, 2010.

(2013. 10. 18 受付)

\title{
CONSTRUCTION TECHNIQUES OF MODERN CIVIL ENGINEERING HERITAGE SEA FORT NO.2 IN TOKYO BAY
}

\author{
Takatoshi NOGUCHI, Kouji URAMOTO and Takeshi SUZUKI
}

100 years has passed after Sea Fort No.2 of Tokyo Bay was constructed in 1907 for military use. The fort suffered damage from Great Kanto Earthquake in 1923, there is a progression of deterioration, damage and collapse of the fort caused by winds and waves of many years. For the reason, measures to preserve the fort are being considered. In this study, we collected information of construction plan, construction techniques and design techniques on the first experience of large-scale sea fort construction in Japan. And, we also verified the information and compiled construction history of the fort. Then, we made discussion that the knowledge is used in present construction techniques. 